\title{
Prototype model taman bacaan masyarakat berbasis ekonomi kreatif creative economic-based community reading park prototype model
}

\author{
Yanti Karmila Nengsih *, Mahyumi Rantina, Vina Amalia Suganda M, Mega Nurrizalia \\ Fakultas Keguruan dan Ilmu Pendidikan, Universitas Sriwijaya. \\ Jl. Ogan, RT.37/RW.12, Bukit Lama, Kota Palembang, Sumatera Selatan 30139, Indonesia \\ *Corresponding Author. Email: yantikn@fkip.unsri.ac.id
}

Received: 18 December 2019; Revised: 23 June 2020; Accepted: 30 August 2020

\begin{abstract}
Abstrak: Penelitian ini bertujuan untuk mengembangkan produk berupa Prototype Model Taman Bacaan Masyarakat (TBM) Berbasis Ekonomi Kreatif di Ogan Ilir. Penelitian pengembangan ini dilaku-kan dengan mempedomani langkah pengembangan model ADDIE (Analyze, Design, Development, Implementation, and Evaluation). Penelitian ini hanya sampai pada tahap validasi ahli yang mengguna-kan 3 ahli yaitu ahli bahasa, ahli materi/isi dan ahli penyajian/media dan 7 orang masyarakat untuk. Instrumen validasi yang digunakan adalah angket. Penelitian ini menggunakan analisis data deskriptif dengan satu variabel yaitu kualitas prototype model Taman Bacaan Masyarakat (TBM) berbasis Ekonomi Kreatif. Hasil penelitian menunjukkan bahwa: (1) model Taman Bacaan Masyarakat (TBM) berbasis Ekonomi Kreatif dengan menerapkan metode montessori yang terdiri dari 2 sentra yaitu sentra literasi baca tulis dan sentra ekonomi kreatif, secara tujuan dinilai layak untuk digunakan oleh masyarakat dalam meningkatkan kegiatan baca tulis dan kegiatan ekonomi kreatif masyarakat, (2) tingkat keterpakaian model Taman Bacaan Masyarakat (TBM) berbasis Ekonomi Kreatif dinilai sangat tinggi untuk digunakan oleh masyarakat.
\end{abstract}

Kata Kunci: Ekonomi Kreatif, Model Taman Bacaan Masyarakat, Literasi, Prototype

\section{Prototype model of community reading park based on creative economy creative economy-based community reading park prototype model}

Abstract: This study aims to develop products in the form of Prototype Model Taman Bacaan Masyarakat (TBM) Based on Creative Economy in Ogan Ilir. This developmental research was carried out by guiding the steps of developing the ADDIE model (Analyze, Design, Development, Implementation, and Evaluation). This study only reached the validation stage of experts who used 3 experts namely linguists, content/content experts and presentation/media experts. The validation instrument used was a questionnaire. This study uses descriptive data analysis with one variable, namely the quality of the prototype model of Community Reading Gardens (TBM) based on the Creative Economy. The results showed that: (1) Creative Economy-based Community Reading Garden (TBM) model by applying the Montessori method consisting of a centers namely literacy centers and creative economic centers, the objectives are considered feasible to be used by the community in increasing literacy activities and the creative economy activities of the community, (2) the level of usage of the Creative Economy-based Community Reading Park (TBM) model is considered very high for community use.

Keywords: Creative Economy, Community Reading Garden Model, Literacy, Prototype

How to Cite: Nengsih, Y., Rantina, M., Suganda M, V., \& Nurrizalia, M. (2020). Prototype model taman bacaan masyarakat berbasis ekonomi kreatif creative economic-based community reading park prototype model. JPPM (Jurnal Pendidikan dan Pemberdayaan Masyarakat), 7(2), 115-123. doi:https://doi.org/10.21831/jppm.v7i2.28652 
JPPM (Jurnal Pendidikan dan Pemberdayaan Masyarakat), 7 (2), 2020 - 116

Yanti Karmila Nengsih, Mahyumi Rantina, Vina Amalia Suganda M, Mega Nurrizalia

\section{PENDAHULUAN}

Pendidikan adalah usaha sadar dan terencana untuk melakukan perubahan kearah yang lebih baik. Pendidikan sangat berperan penting dalam meningkatkan kualitas sumber daya manusia. Untuk memperoleh pendidikan, biasanya masyarakat belajar lewat sekolah, kampus, bimbingan belajar, maupun instansi sejenis. Akan tetapi, tidak semua masyarakat bisa memperoleh pendidikan secara merata dan layak, masih banyak diantara mereka yang belum mendapatkan hak yang sama dalam memperoleh pendidikan. Hal tersebut muncul karena sebuah alasan, yakni ekonomi keluarga, internal sekolah atau psikis pribadi seseorang yang tidak mau bersekolah dan belajar.

Sudah menjadi kenyataan bahwa tuntutan perkembangan zaman pada era globalisasi, manusia dituntut untuk terampil dan memiliki daya saing. Efek dari globalisasi juga berdampak pada dunia pendidikan yang dirasakan oleh masyarakat Indonesia. Angka penggangguran terbuka pada Agustus 2018 berjumlah 6,87 juta orang atau 5,13\%. Kepala BPS Suhariyanto mengatakan, jika dilihat menurut pendidikan tertinggi maka persentase pengangguran tamatan Sekolah Menengah Kejuruan (SMK) sebesar 8,92\%. Sedangkan untuk pendidikan SD ke bawah angkanya 2,67\%, lalu sekolah menengah pertama (SMP) 5,18\%, Universitas 6,31\%, sekolah menengah atas (SMA) 7,19\%, dan Diploma I-III sebesar 7,92\% (bps.go.id).

Upaya dalam meningkatkan kualitas sumber daya manusia dalam rangka persaingan pada era globalisasi, maka pendidikan harus dikembangkan dan ditingkatkan. Agar mampu bersaing diperlukan sumber daya manusia yang berkualitas, enerjik, cerdas, dan terampil dalam bidangnya, sehingga mampu memenangkan persaingan dalam bidang pendidikan. Sesuai dengan amanat Undang-Undang No 20 tahun 2003 pasal 13 tentang Sistem Pendidikan Nasional, jalur pendidikan dibagi menjadi tiga jalur yaitu pendidikan formal, pendidikan non formal dan pendidikan informal yang dapat saling melengkapi. Ketiga jenis pendidikan ini berfungsi mengembangkan kemampuan dan membentuk watak serta peradaban bangsa yang bermartabat dalam rangka mencerdaskan kehidupan bangsa. Melalui ketiga jenis pendidikan ini diharapkan potensi peserta didik berkembang dan menjadi bangsa Indonesia yang beriman dan bertakwa kepada tuhan Yang Maha Esa.

Pendidikan luar sekolah (pendidikan nonformal) turut berperan dalam menciptakan sumber daya manusia yang berkualitas melalui satuan pendidikan yaitu pendidikan formal, pendidikan informal, dan pendidikan nonformal. Pendidikan luar sekolah menurut Joesoef (1992:5) adalah segala kegiatan yang terorganisir yang diselenggarakan di luar sistem pendidikan formal, baik tersendiri maupun merupakan bagian dari kegiatan yang jelas yang dimaksudkan untuk memberikan layanan pada sasaran didik tertentu dalam mencapai tujuan belajar.

Pendidikan nonformal berperan dalam meningkatkan mutu sumber daya manusia, salah satunya yaitu melalui program Taman Bacaan Masyarakat (TBM) yang telah banyak diberbagai daerah. Taman bacaan masyarakat hendaknya berupaya untuk mendayagunakan sumbersumber, baik personal maupun material, secara efektif dan efisien guna menunjang tercapainya tujuan pendidikan Indonesia yaitu mencerdaskan anak bangsa dan tidak melihat stratifikasi sosial masyarakat. Dalam rangka mewujudkan tujuan pendidikan, berbagai taman bacaan mulai bermunculan, e-book dan perpustakaan canggih lainnya.

Akan tetapi fakta terbalik membuktikan bahwa minat baca masyarakat Indonesia masih tergolong rendah. Berdasarkan data dari Badan Pusat Statistik (BPS), pada tahun 2006, tercatat penduduk yang berumur di atas 10 tahun yang mendengarkan radio berjumlah 40,26\%, menonton TV berjumlah $85,86 \%$, dan yang membaca surat kabar berjumlah $23,46 \%$. Selanjutnya pada tahun 2009, penduduk yang mendengarkan radio berjumlah $23,50 \%$, menonton TV berjumlah 90,27\%, dan membaca surat kabar berjumlah 18,94\%. Terakhir pada tahun 2012 menunjukkan bahwa penduduk yang mendengarkan radio berjumlah $18,57 \%$, menonton TV berjumlah $91,68 \%$, dan yang membaca surat kabar berjumlah 17,66\%. (Sartono, dalam www.bps.go.id).

Menurut data kemendikbud tahun 2017 jumlah Taman Bacaan Masyarakat (TBM) di Ogan Ilir ada 2 yaitu Unsri Mengajar dan Sriwijaya Membaca. Pada prakteknya kedua TBM ini baru 
JPPM (Jurnal Pendidikan dan Pemberdayaan Masyarakat), 7 (2), 2020 - 117

Yanti Karmila Nengsih, Mahyumi Rantina, Vina Amalia Suganda M, Mega Nurrizalia

menerapkan kegiatan gerakan literasi (baca tulis). Oleh karena itu penulis ingin mengembangkan suatu model Taman Bacaan Masyarakat (TBM) yang berbasis ekonomi kreatif, dimana dalam pengaplikasian model TBM yang dirancang akan menerapkan metode Montessori yang terbagi beberapa sentra yaitu sentra aksara, sentra ekonomi dan sentra seni. Hal ini bertujuan untuk meningkat minat baca dan menumbuhkan kreativitas masyarakat. Yang mana pada saat sekarang setiap manusia dituntut untuk memiliki keterampilan agar mampu bersaing di era globalisasi.

Selain itu diharapkan penelitian ini juga bias menunjang program pemerintah dalam menguat literasi dasar untuk masyarakat di segi literasi ekonomi atau keuangan. Dari hasil penelitian menunjukkan literasi ekonomi juga bias di kembangkan oleh Taman Bacaan Masyarakat (TBM) salah satunya melalui kegiatan ekonomi kreatif atau keterampilan.

Menurut Manurung (2009, p.24) literasi keuangan adalah seperangkat keterampilan dan pengetahuan yang memungkinkan seorang individu untuk membuat keputusan yang efektif dengan menggunakan semua sumber daya keuangan mereka. sehingga literasi keuangan sangat penting dalam meningkatkan kesejahteraan individu, dimana pengetahuan keuangan yang dimiliki dapat mendorong dalam mengambil keputusan keuangan (Widyawati, 2012).

Berdasarkan pernyataan tersebut, penelitian ini bermaksud mengembangkan suatu produk model pusat pembelajaran berupa Taman Bacaan Masyarakat (TBM) berbasis ekonomi kreatif. Dengan demikian, model TBM yang dikembangkan dapat membantu masyarakat dalam mengembangkan kegiatan pembelajaran berupa kegiatan baca tulis, keterampilan berwirausaha, dan kesenian.

\section{METODE}

Berdasarkan rumusan masalah yang sudah dikemukan di atas, maka jenis penelitian ini adalah menggunakan jenis penelitian pengembangan atau sering juga disebut dengan Research and Development (R\&D) yang menghasilkan produk berupa model Taman Bacaan Masyarakat (TBM). Menurut Sugiyono (2012, p.407) penelitian dan pengembangan adalah metode penelitian yang digunakan untuk menghasilkan produk tertentu, dan menguji keefektifan produk tersebut. Penelitian dan pengembangan merupakan pendekatan penelitian yang menghasilkan produk baru atau menyempurnakan produk yang telah ada (Sukmadinata, 2007, p.169).

Penelitian ini bertujuan untuk mengembangkan model Taman Bacaan Masyarakat (TBM) berbasis ekonomi kreatif dengan konsep sentra yang pada penerapannya mengunakan dua sentra yaitu sentra literasi baca tulis dan bermain untuk anak-anak dan sentra ekonomi kreatif dan dimanfaatkan oleh para orangtua. Menurut Sugiyono (2015, p.200) prosedur penelitian ini mengadaptasi model pengembangan ADDIE yang terdiri dari lima tahapan yang meliputi analisis (analysis), desain (design), pengembangan (development), implementasi (implementation) dan evaluasi (evaluation).

Maka penelitian dan pengembangan merupakan metode untuk menghasilkan suatu produk tertentu atau menyempurnakan produk yang telah ada serta menguji keefektifan produk tersebut. Peneliti ingin melakukan penelitian dan pengembangan model Taman Bacaan Masyarakat (TBM) berbasis ekonomi kreatif. Tingkat kelayakan model TBM dianalisi melalui validasi oleh ahli materi, validasi oleh ahli bahasa, penyajian dan konten serta diuji coba penggunaannya oleh warga masyarakat sasaran.

Penelitian ini berlokasi di Indralaya Ogan Ilir. Alasan dipilihnya lokasi penelitian karena TBM yang ada cenderung hanya bergerak pada kegiatan belajar baca tulis dan penyediaan peminjaman buku bacaan. Penelitian ini akan dilakukan selama 12 bulan mulai dari penyusunan proposal, melakukan penelitian, hasil penelitian dan publikasi hasil penelitian yaitu Januari sampai Desember 2019.

Prosedur pengembangan yang diterapkan dalam penelitian ini mengikuti langkah-langkah pengembangan menurut model ADDIE yang meliputi Analysis, Design, Development, Implementation, dan Evaluation. Adapun langkah penelitian pengembangan dalam penelitian 
JPPM (Jurnal Pendidikan dan Pemberdayaan Masyarakat), 7 (2), 2020 - 118

Yanti Karmila Nengsih, Mahyumi Rantina, Vina Amalia Suganda M, Mega Nurrizalia

ini disajikan dalam bentuk bagan proses pengembangan model ADDIE menurut Grafinger, (1988) dalam Molenda (2003, p.2).

Responden pada penelitian ini berjumlah 10 orang yaitu 3 orang validator model TBM berbasis Ekonomi Kreatif dan 7 orang masyarakat sasaran di lokasi pengembangan model. Produk akan divalidasi oleh 3 orang ahli yang terdiri dari ahli bahasa, ahli materi/isi dan ahli penyajian/media. Instrumen validasi yang digunakan adalah angket. Penelitian ini menggunakan analisis data deskriptif dengan satu variabel yaitu kualitas prototype model Taman Bacaan Masyarakat (TBM) berbasis Ekonomi Kreatif.

\section{HASIL DAN PEMBAHASAN}

\section{Hasil Pengembangan Taman Bacaan Masyarakat (TBM) berbasis Ekonomi Kreatif}

Berdasarkan pengembangan model Taman Bacaan Masyarakat (TBM) berbasis Ekonomi Kreatif dengan tahapan pengembangan model ADDIE sampai pada uji coba kelompok kecil, maka diperoleh hasil sebagai berikut:

\section{Hasil Analisis Kebutuhan}

Analisis kebutuhan masyarakat terhadap Taman Bacaan Masyarakat (TBM) yang peneliti lakukan dengan memberikan kuesioner tertutup kepada masyarakat. Tahapan ini bertujuan untuk mengetahui tingkat kebutuhan masyarakat terhadap TBM. Karena kegiatan ekonomi kreatif bisa diintegrasikan dengan Taman Bacaan Masyarakat (TBM), maka peneliti memilih merancang model Taman Bacaan Masyarakat (TBM) berbasis ekonomi kreatif. Peneliti memilih ekonomi kreatif, karena sesuai dengan perkembangan zaman pada saat ini yaitu ekonomi kreatif lagi berkembang di masyarakat dan mampu memberikan sumbangsih yang besar di dalam mensejahterakan masyarakat. Selain itu minat baca masyarakat Indonesia yang masih tergolong tertinggal dari Negara tetangga, sehingga diharapkan dengan Model TBM Berbasis Ekonomi Kreatif ini, tercipta masyarakat yang gemar membaca dan mengaplikasikan apa yang mereka baca dalam bentuk keterampilan produktif yang mengasilkan pundi-pundi uang.

Peneliti telah memberikan kuesioner kepada masyarakat di lokasi sasaran tempat penelitian yaitu sebanyak 7 orang responden. Hasil dari kuisioner dapat dilihat di Tabel 1.

Tabel 1. Hasil kuisioner

\begin{tabular}{|c|c|c|c|c|}
\hline No. & Pertanyaan & Pilihan Jawaban & $\begin{array}{c}\text { Jawaban } \\
\text { Masyarakat }\end{array}$ & Persentase \\
\hline 1. & $\begin{array}{l}\text { Apakah kamu tahu tentang Taman } \\
\text { Bacaan Masyarakat (TBM)? }\end{array}$ & $\begin{array}{l}\text { a. Sangat tahu } \\
\text { b. Tahu } \\
\text { c. Kurang tahu } \\
\text { d. Tidak tahu }\end{array}$ & $\begin{array}{l}11 \\
11111\end{array}$ & $\begin{array}{l}28,57 \% \\
71,43 \%\end{array}$ \\
\hline 2. & $\begin{array}{l}\text { Apakah Taman Bacaan Masyarakat } \\
\text { (TBM) perlu didirikan sebagai } \\
\text { tempat masyarakat belajar baca tulis } \\
\text { dan keterampilan? }\end{array}$ & $\begin{array}{l}\text { a. Sangat perlu } \\
\text { b. Perlu } \\
\text { c. Kurang perlu } \\
\text { d. Tidak perlu }\end{array}$ & 1111111 & $100 \%$ \\
\hline 3. & $\begin{array}{l}\text { Bagaimana ketersediaan sumber } \\
\text { bacaan di rumah mu? }\end{array}$ & $\begin{array}{ll}\text { a. } & \text { Sangat lengkap } \\
\text { b. Lengkap } \\
\text { c. Kurang lengkap } \\
\text { d. Tidak ada }\end{array}$ & $\begin{array}{l}111111 \\
1\end{array}$ & $\begin{array}{l}85,7 \% \\
14,3 \%\end{array}$ \\
\hline 4. & $\begin{array}{l}\text { Bagaimana pendapat kamu jika ada } \\
\text { Taman Bacaan Masyarakat (TBM) } \\
\text { yang menyediakan buku bacaan dan } \\
\text { tempat belajar keterampilan? }\end{array}$ & $\begin{array}{ll}\text { a. } & \text { Sangat setuju } \\
\text { b. Setuju } \\
\text { c. Kurang setuju } \\
\text { d. Tidak setuju }\end{array}$ & 1111111 & $100 \%$ \\
\hline 5. & $\begin{array}{l}\text { Bagaimana model Taman Bacaan } \\
\text { Masyarakat (TBM) yang kamu } \\
\text { harapkan? }\end{array}$ & $\begin{array}{l}\text { a. Memiliki koleksi buku } \\
\text { dan area bermain } \\
\text { b. Ada kegiatan bermain }\end{array}$ & 1 & $14,3 \%$ \\
\hline
\end{tabular}


JPPM (Jurnal Pendidikan dan Pemberdayaan Masyarakat), 7 (2), 2020 - 119

Yanti Karmila Nengsih, Mahyumi Rantina, Vina Amalia Suganda M, Mega Nurrizalia

\begin{tabular}{|c|c|c|c|c|}
\hline No. & Pertanyaan & Pilihan Jawaban & $\begin{array}{c}\text { Jawaban } \\
\text { Masyarakat }\end{array}$ & Persentase \\
\hline \multirow{6}{*}{6.} & \multirow{6}{*}{$\begin{array}{l}\text { Menurutmu, perlukah membentuk } \\
\text { Taman Bacaan Masyarakat (TBM) } \\
\text { dengan memisahkan antara tempat } \\
\text { baca tulis dengan tempat belajar } \\
\text { keterampilan? }\end{array}$} & $\begin{array}{ll}\text { c. } & \begin{array}{l}\text { Pembelajaran } \\
\text { keterampilan }\end{array}\end{array}$ & 11 & $28,6 \%$ \\
\hline & & d. Sesuai kebutuhan & 1111 & $57,1 \%$ \\
\hline & & a. Sangat perlu & 11 & $28,57 \%$ \\
\hline & & b. Perlu & 11111 & $71,43 \%$ \\
\hline & & c. Kurang perlu & & \\
\hline & & Tidak perlu & & \\
\hline \multirow[t]{2}{*}{7.} & $\begin{array}{l}\text { Menurut anda, apa bentuk sarana } \\
\text { dan prasarana yang perlu tersedia di } \\
\text { Taman Bacaan Masyarakat (TBM)? }\end{array}$ & $\begin{array}{l}\text { a. Rak buku, meja dan } \\
\text { kursi, alat tulis, APE, } \\
\text { ruang belajar (spt aula, } \\
\text { alam terbuka dll) }\end{array}$ & 11111 & $71,43 \%$ \\
\hline & & $\begin{array}{l}\text { b. Berbagai macam Alat } \\
\text { permainan edukatif } \\
\text { c. Tikar } \\
\text { d. Lampu }\end{array}$ & 11 & $28,57 \%$ \\
\hline \multirow[t]{4}{*}{8.} & Bagaimana pelayanan Taman & a. Menyenangkan & 1 & $14,3 \%$ \\
\hline & Bacaan Masyarakat (TBM) yang & b. Bersih & 1 & $14,3 \%$ \\
\hline & kamu harapkan? & c. Nyaman & 11 & $28,6 \%$ \\
\hline & & d. Semuanya & 111 & $42,9 \%$ \\
\hline \multirow[t]{3}{*}{9.} & Menurut anda, apa jenis buku & a. Buku Keterampilan & 1 & $14,3 \%$ \\
\hline & bacaan yang ingin disediakan? & $\begin{array}{l}\text { b. Novel dan Buku Cerita } \\
\text { c. Buku berGambar }\end{array}$ & 11 & $28,6 \%$ \\
\hline & & d. Semuanya & 1111 & $57,1 \%$ \\
\hline \multirow[t]{4}{*}{10.} & $\begin{array}{l}\text { Menurut anda, jenis keterampilan } \\
\text { yang harus diberikan pada warga }\end{array}$ & $\begin{array}{l}\text { a. Disesuaikan dengan } \\
\text { kemampuan masyarakat }\end{array}$ & 1111 & $57,1 \%$ \\
\hline & $\begin{array}{l}\text { belajar di Taman Bacaan Masyarakat } \\
\text { (TBM)? }\end{array}$ & $\begin{array}{l}\text { b. Dibeda-bedakan setiap } \\
\text { kali pertemuan }\end{array}$ & 1 & $14,3 \%$ \\
\hline & & $\begin{array}{l}\text { Keterampilan untuk } \\
\text { berwirausaha }\end{array}$ & 11 & $28,6 \%$ \\
\hline & & $\begin{array}{l}\text { d. Kemampuan berjualan } \\
\text { online }\end{array}$ & & \\
\hline \multirow[t]{4}{*}{11.} & Menurut anda, apakah perlu & a. Sangat perlu & 111 & $42,9 \%$ \\
\hline & instruktur dalam membimbing & b. Perlu & 1111 & $57,1 \%$ \\
\hline & masyarakat untuk mempraktekkan & c. Kurang perlu & & \\
\hline & $\begin{array}{l}\text { keterampilan yang sudah dibaca } \\
\text { pada buku keterampilan? }\end{array}$ & d. Tidak perlu & & \\
\hline \multirow[t]{4}{*}{12.} & $\begin{array}{l}\text { Jika anda ingin membuka usaha } \\
\text { setelah mempraktekkan }\end{array}$ & $\begin{array}{l}\text { aembangun toko di } \\
\text { dekat rumah }\end{array}$ & 111 & $42,9 \%$ \\
\hline & keterampilan, bentuk usaha apa & b. Berjualan online & 1 & $14,3 \%$ \\
\hline & yang ingin dijalankan? & c. Memanfaatkan & 111 & $42,9 \%$ \\
\hline & & $\begin{array}{ll} & \text { lingkungan sekitar } \\
\text { d. } & \text { Berjualan keliling }\end{array}$ & & \\
\hline
\end{tabular}

Dari penjabaran data pada Tabel 1, dapat disimpulkan bahwa masyarakat membutuhkan kehadiran Taman Bacaan Masyarakat (TBM) berbasis ekonomi kreatif sebagai sarana untuk belajat meningkatkan minat baca dan keterampilan ekonomi kreatif, sehingga bias diterapkan untuk kehidupan sehari-hari.

\section{Desain Model TBM berbasis Ekonomi Kreatif}

Pengembangan model TBM berbasis Ekonomi Kreatif, dikembangkan mulai dari beberapa bagian yaitu (1) Nama, (2) Logo, (3) Desain, dan (4) Alur belajar dengan menggunakan metode moentessori atau yang lebih dikenal dengan pembelajaran sentra.

Bagan 1 Rancangan Model TBM Berbasis Ekonomi Kreatif 
JPPM (Jurnal Pendidikan dan Pemberdayaan Masyarakat), 7 (2), 2020 - 120

Yanti Karmila Nengsih, Mahyumi Rantina, Vina Amalia Suganda M, Mega Nurrizalia

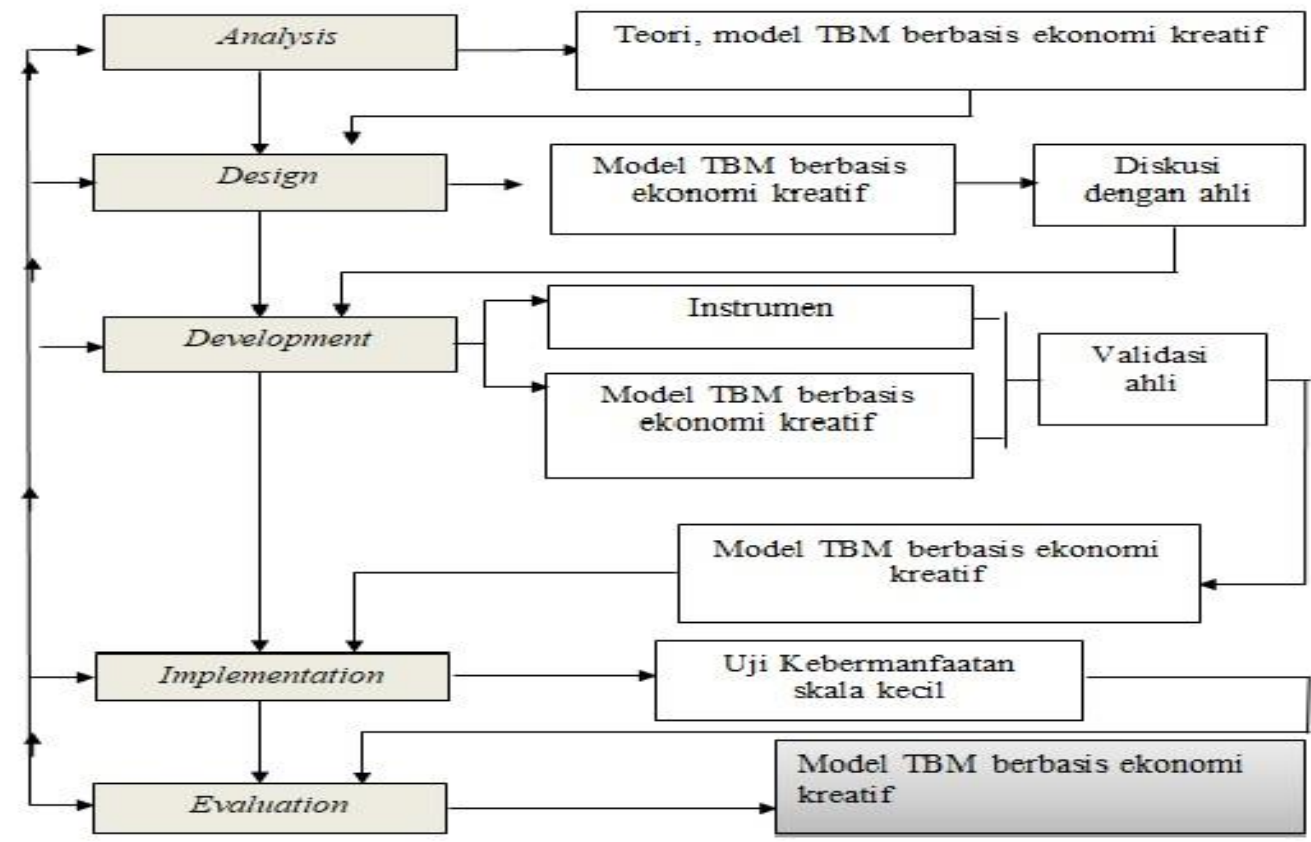

Gambar 1. Nama TBM: Taman Bacaan Masyarakat (TBM) Cipta Kreatif Bangsa

Logo

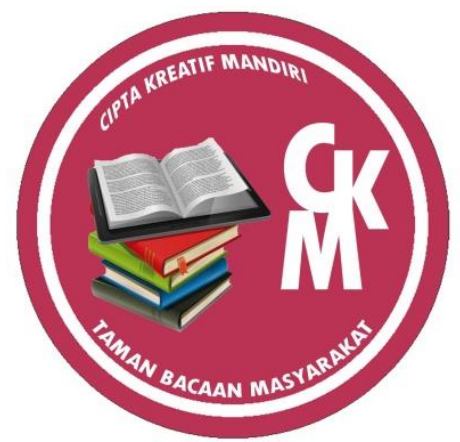

Gambar 2. Logo Taman Bacaan Masyarakat

Desain dan Alur Belajar di Taman Bacaan Masyarakat (TBM) berbasis Ekonomi Kreatif TAMAN BACAAN MASYARAKAT (TBM) BERBASIS EKONOMI KREATIF
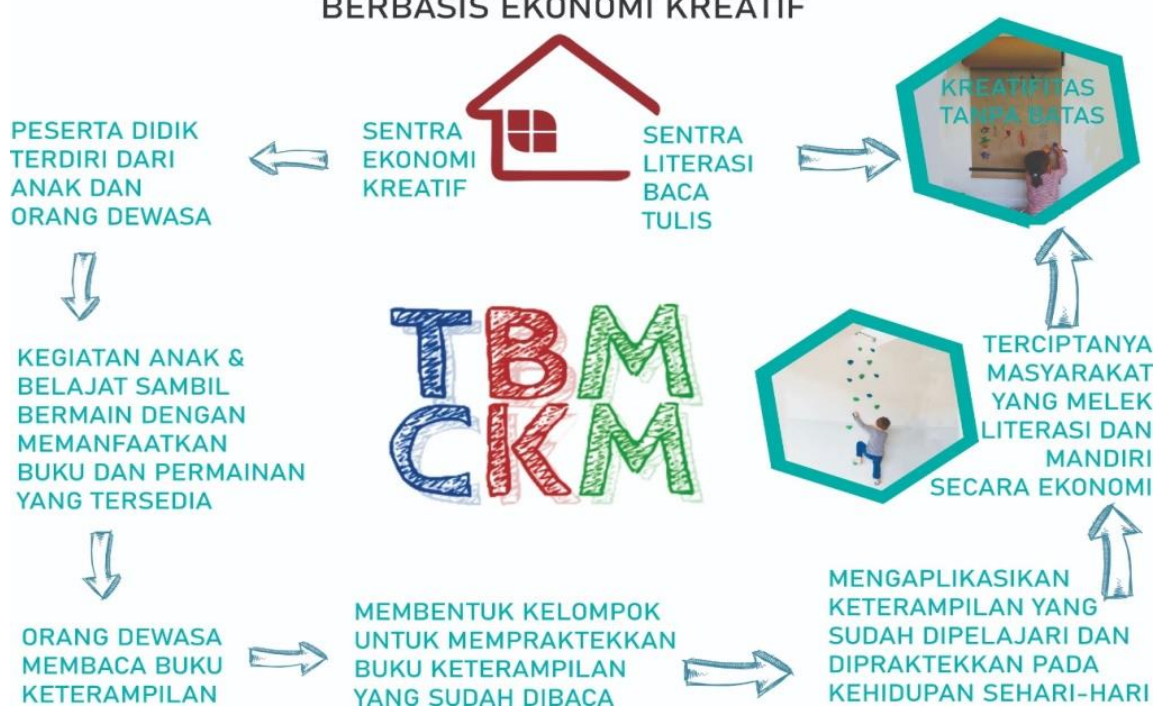

Gambar 3. Desain dan Alur Belajar

Copyright (C) 2020, JPPM, ISSN 2355-1615 (print), ISSN 2477-2992 (online) 
JPPM (Jurnal Pendidikan dan Pemberdayaan Masyarakat), 7 (2), 2020 - 121

Yanti Karmila Nengsih, Mahyumi Rantina, Vina Amalia Suganda M, Mega Nurrizalia

\section{Pengembangan TBM berbasis Ekonomi Kreatif}

Pada umumnya Taman Bacaan Masyarakat (TBM) yang telah ada di lingkungan masyarakat Indralaya ialah sejenis TBM yang memfasilitasi masyarakat dengan menyediakan buku bacaan dan tempat untuk belajar baca tulis. Sehingga pada proses pengembangan TBM, peneliti menekankan pada aspek pengembangan TBM berbasis ekonomi ktearif yang mana bertujuan selain meningkatkan minat baca masyarakat juga membekali masyarakat dengan keterampilan yang kreatif. Sehingga masyarakat memiliki bekal untuk membuka peluang usaha secara mandiri dan mendukung peningkatan literasi ekonomi masyarakat yang masih rendah.

\section{Implementasi model TBM berbasis Ekonomi Kreatif}

Peneliti mengatur tata letak di Taman Bacaan Masyarakat menjadi 2 sentra yaitu sentra literasi baca tulis dan sentra keterampilan ekonomi produkstif. Pertama, sentra literasi baca tulis ditata dengan berbagai macam buku bacaan, alat permainan edukatif, dan alat-alat tulis. Sentra ini cocok dinikmati oleh anak-anak mulai dari usia dini maupun remaja. Kedua, sentra keterampilan ekonomi kreatif yang mana pada sentra ini tata letaknya didesain dengan menyediakan buku-buku tentang keterampilan dan pengunjung atau pembaca diminta untuk membaca buku yang ia minati, setelah selesai membaca bagian keterampilan yang pembaca minati maka tahap selanjutnya, pengunjung didampingi untuk mempraktekkan keterampilan yang telah ia baca sebelumnya.

Peneliti selalu mencoba untuk melakukan evaluasi setelah kegiatan dilakukan disetiap sentra. Apabila ada beberapa hal yang perlu diperbaiki, maka untuk tahap selanjutnya akan dilakukan perbaikan. Adapun model yang dikembangkan ini, memiliki nama Taman Bacaan Masyarakat (TBM) Cipta Kreatif Mandiri, yang mana peneliti maknai bahwa TBM ini menjadi wadah untuk masyarakat belajar dan menumbuhkan minat baca, serta menciptakan kreatifitaskreatifitas sehingga masyarakat mandiri secara pengetahuan dan sejahtera dalam perekonomian.

\section{Validasi model TBM berbasis Ekonomi Kreatif}

Adapun tahapan validasi terhadap produk yang peneliti kembangkan yaitu mulai dari validasi bahasa, validasi konten atau isi dan validasi kelayakan. Kelayakan bahasa divalidasi pada tanggal 1 November 2019 oleh Ibu Armilia Sari S.Pd., M.Pd, dosen Program Studi Pendidikan Bahasa dan Sastra Indonesia FKIP Unsri. Pada aspek kelayakan bahasa ini, penilaian diberikan dengan nilai minimal 1 dan nilai maksimal 4. Ketepatan struktur kalimat mendapat nilai 4, keefektifan kalimat mendapat nilai 3, pemahaman terhadap pesan atau informasi mendapat nilai 3, kemampuan memotivasi mendapat nilai 4, kesesuaian dengan tingkat perkembangan intelektual mendapat nilai 3, kesesuaian dengan perkembangan emosional mendapat nilai 3, ketepatan tata bahasa mendapat nilai 3, dan ketepatan ejaan mendapat nilai 4. Validator bahasa menyatakan bahwa model TBM ini layak digunakan dengan revisi terlebih dahulu.

Kelayakan isi atau materi divalidasi pada tanggal 2 November 2019 oleh Ibu Dr. Azizah Husin, M.Pd., dosen Program Studi Pendidikan Luar Sekolah FKIP Unsri. Pada aspek kelayakan isi atau materi, nilai yang diberikan minimal 1 dan maksimal nilai 4. Kelengkapan materi mendapat nilai 4, keluasan materi mendapat nilai 4, kedalaman materi mendapat nilai 4, keakuratan konsep dan definisi mendapat nilai 3, keakuratan data dan fakta mendapat nilai 3, keakuratan gambar, diagram, dan ilustrasi mendapat nilai 4, keakuratan istilah-istilah mendapat nilai 4, mendorong rasa ingin tahu mendapat nilai 4 , dan menciptakan kemampuan bertanya mendapat nilai 4. Validator kelayakan isi memutuskan bahwa model TBM ini layak untuk digunakan dengan revisi terlebih dahulu.

Adapun, kelayakan penyajian divalidasi pada tanggal 5 November 2019 oleh Dr. Didi Tahyudin, M.Pd., dosen Pendidikan Luar Sekolah. Pada aspek kelayakan penyajian, nilai yang diberikan minimal 1 dan maksimal 4. Keruntutan konsep mendapat nilai 4, kejelasan tujuan nilai 4, kelengkapan informasi mendapat nilai 3, indikator pembelajaran mendapat nilai 3, petunjuk 
JPPM (Jurnal Pendidikan dan Pemberdayaan Masyarakat), 7 (2), 2020 - 122

Yanti Karmila Nengsih, Mahyumi Rantina, Vina Amalia Suganda M, Mega Nurrizalia

belajar mendapat nilai 4, daftar pustaka mendapat nilai 3, pemberian motivasi mendapat nilai 4, dan interaksi keterlibatan peserta didik mendapat nilai 4. Validator penyajian menyimpulkan bahwa Model Taman Bacaan Masyarakat (TBM) berbasis ekonomi kreatif ini layak digunakan dengan revisi terlebih dahulu.

Setelah dilakukan validasi dari ahli, peneliti melakukan revisi sesuai dengan komentar dan saran yang diberikan oleh tim validator.

\section{Keterbatasan Pengembangan}

Penelitian ini telah selesai penulis laksanakan sesuai dengan kesempatan dan kemampuan yang dimiliki. Berbagai upaya telah dilakukan untuk mencapai hasil yang optimal dan telah berupaya untuk mengikuti prosedur dan tahap-tahap yang disyaratkan sebagai karya ilmiah. Namun peneliti menyadari bahwa penelitian pengembangan ini masih banyak memiliki keterbatasan. Adapun keterbatasan pengembangan ini diuraikan sebagai berikut.

Pengembangan produk dalam penelitian hanya sampai pada aspek validasi oleh ahli yang dilakukan oleh 3 orang ahli, terdiri dari ahli bahasa, ahli materi/isi dan ahli penyajian/media, dan Pengkajian aspek keterpakaian produk dalam penelitian ini belum dilakukan

Harapan peneliti untuk peneliti selanjutnya agar penelitian ini dapat ditindaklanjuti dengan melakukan eksperimen pada uji coba lapangan untuk melihat efektifitas dan kontribusi yang dapat diberikan untuk menumbuhkan minat baca masyarakat dan kreatifitas dalam menciptakan ekonomi kreatif, sehingga produk penelitian yang dihasilkan dapat digunakan oleh masyarakat secara luas. Terkait dengan segala keterbatasan pengembangan ini semoga produk penelitian yang dihasilkan berguna dan bermanfaat bagi masyarakat dan perkembangan pendidikan nonformal ke depannya.

\section{SIMPULAN}

Berdasarkan analisa data produk didapatkan hasil pada uji coba produk dilakukan oleh tiga orang ahli yaitu ahli materi, ahli bahasa dan ahli penyajian/desain media dengan kategori sangat layak digunakan. Berdasarkan hasil penelitian tersebut, secara umum dapat disimpulkan bahwa produk penelitian yang dihasilkan dinyatakan layak dan dapat dipakai untuk masyarakat dalam rangka meningkatkan minat baca dan menciptakan kreatifitas dalam bidang ekonomi kreatif. Dengan demikian produk hasil penelitian ini dapat direkomendasikan untuk diperkenalkan dan digunakan oleh masyarakat secara lebih luas.

Hasil penelitian berupa prototype model TBM berbasis ekonomi kreatif dinyatakan layak dan dapat dipakai oleh masyarakat. Hal ini mengidentifikasikan bahwa produk yang dihasilkan dalam penelitian ini dapat diterima oleh masyarakat. Dengan hadirnya produk yang dihasilkan dari penelitian ini, maka masyarakat semakin memiliki semangat untuk meningkatkan minat baca dan kreatifitasnya.

Produk yang dihasilkan yaitu prototype model TBM berbasis ekonomi kreatif bukan satusatunya sarana bagi masyarakat untuk membantu masyarakat dalam meningkatkan minat baca dan keterampilan (kreatifitas) untuk kehidupan sehari-hari. Masyarakat diharapkan dalam menggunakan produk ini memperhatikan kesiapan dan ketersediaan alat dan bahan yang akan digunakan pada waktu praktik keterampilan, sehingga tidak memberatkan masyarakat dalam menerapkannya. Dalam praktiknya, produk penelitian ini akan dapat terlaksana dengan baik apabila masyarakat memiliki kelengkapan alat pendukung.

Model TBM yang dikembangkan ini berupa prototype yang masih memiliki banyak kekuarangan karena baru sampai pada tahap validasi ahli. Ujicoba penggunaan model untuk masyarakat dalam kelompok kecil dan lebih luas diperlukan perumusan yang tepat sesuai dengan karakteristik masyarakat yang beragam. Keilmuan ataupun keterampilan yang akan diajarkan perlu pengembangan lebih lanjut sesuai dengan kebutuhan masyarakat dan perkembangan zaman. 
JPPM (Jurnal Pendidikan dan Pemberdayaan Masyarakat), 7 (2), 2020 - 123

Yanti Karmila Nengsih, Mahyumi Rantina, Vina Amalia Suganda M, Mega Nurrizalia

\section{DAFTAR PUSTAKA}

Hatimah, I. (2007). Pembelajaran berwawasan kemasyarakatan. Jakarta: Universitas Terbuka. Joesoef, S. (1992). Konsep dasar pendidikan luar sekolah. Bumi Aksara.

Kalida, M. (2012). Fundraising taman bacaan masyarakat (TBM). Yogyakarta: Aswaja dan Cakruk Publising.

Kementerian Pendidikan dan Kebudayaan, Ditjen PAUDNI, Direktorat Pembinaan Pendidikan Masyarakat. 2013. Taman Bacaan Masyarakat Ruang Publik. Jakarta

Manurung, J., \& Manurung, A. H. (2009). Ekonomi keuangan dan kebijakan moneter. Jakarta: Salemba Empat.

Sugiyono (2015). Metode penelitian kombinasi (Mix Methods). Bandung: Alfabeta

Sugiyono, S. (2010). Metode penelitian pendidikan. Pendekatan Kuantitatif. Bandung: Alfabeta.

Sukmadinata, N. S. (2007). Metode penelitian pendidikan. Bandung: Remaja Rosda Karya.

Widyawati, I. (2012). Faktor-faktor yang mempengaruhi literasi finansial mahasiswa fakultas ekonomi dan bisnis Universitas Brawijaya. Assets: Jurnal Akuntansi dan Pendidikan, 1(1), 89-99. 